\title{
Perceived Organizational Red Tape and Organizational Performance in Public Services
}

Christian Bøtcher Jacobsen is associate professor of public administration in the Department of Political Science, Aarhus University, Denmark. His research mainly focuses on leadership, motivation, and performance in public service organizations. He is currently working on a large-scale field-experimental project on leadership (The LEAP project). E-mail: christianj@ps.au.dk

Mads Leth Jakobsen is associate professor in the Department of Political Science, Aarhus University, Denmark. His research covers subjects such as bureaucratization, red tape, innovative behavior, organizational learning, and performance management within a public management perspective. He is in charge of the Professional Master in Public Governance program at Aarhus University and University of Southern Denmark. For more information, see http://au.dk/en/ mads@ps.

E-mail: mads@ps.au.dk
Public Administration Review, Vol. 78, Iss. 1, pp. 24-36. @ 2017 by The American Society for Public Administration. DOI: 10.1111/puar.12817.

Abstract: The claim that perceived organizational red tape hampers public services has become a central theme in public administration research. Surprisingly, however, few scholars have empirically examined the impact of perceived red tape on organizational performance. This article empirically analyzes how perceived organizational red tape among managers and frontline staff relates to objectively measured performance. The data consist of survey responses from teachers and principals at Danish upper secondary schools combined with grade-level administrative performance data. Based on theories of red tape and motivation crowding, the authors hypothesize that perceived organizational red tape reduces performance within such organizations. The empirical result is a small negative relationship between staff perception of red tape and performance and no relationship between manager-perceived red tape and performance.

\section{Evidence for Practice}

- Public administration theories predict that perceptions of organizational red tape will reduce performance by constraining employees and reducing their motivation.

- Employees perceive significantly higher levels of red tape than managers.

- Employee-perceived red tape (but not manager-perceived red tape) is negatively but weakly associated with objectively measured performance.

$\mathrm{R}$ ed tape is a central topic in public administration research and one of the most investigated in recent decades (Bozeman and Feeney 2011). The negative implications of red tape for performance in public organizations is perhaps the most central claim in the literature, which is theoretically explained with reference to burdensome rules. In practice, however, almost all studies measure red tape subjectively rather than objectively. Furthermore, although originally presented as a central motivation for the study of red tape (Bozeman and Feeney 2011, 99), there is surprisingly little theory or empirical evidence regarding the impact of organizational red tape on organizational performance. the perception that rules have negative consequences follows Kaufman's classic point that red tape is about how people "mean that they are subjected to too many constraints" $(1977,5)$. We lack both theoretical and empirical knowledge about the relationship between perceived red tape and objectively measured performance, however, and this article provides three contributions to the literature.

First, we show that the perception of red tape among frontline staff is negatively related to objectively measured performance. Nonetheless, the relationship is weaker than that found in existing studies based on perceptual performance measures (Brewer and Walker 2010b), which can be subject
This article aims to advance our understanding of red tape by theorizing and examining how perceptions of red tape among public managers and frontline staff can affect organizational performance. Perceived organizational red tape refers to a belief among organizational actors that rules within and outside the organization are detrimental to organizational performance. Defining red tape as
This article aims to advance our understanding of red tape by theorizing and examining how perceptions of red tape among public managers and frontline staff can affect organizational performance. to common-source bias (Favero and Bullock 2015; Jakobsen and Jensen 2015; Podsakoff and Organ 1986). The article uses objective performance measures and controls for past performance in order to account for performance being highly autoregressive (Meier and O'Toole 1999). These are necessary steps if we are to increase our empirical knowledge of this issue. 
Second, based on red tape theory (Pandey, Coursey, and Moynihan 2007; Pandey and Moynihan 2006) and motivation-crowding theory (Frey 1997; Jacobsen, Hvitved, and Andersen 2014), we develop the theory behind the hypothesis that perceived red tape negatively affects performance in public service organizations. The key mechanisms are that perceived red tape constrains and demotivates employees.

Third, existing studies mainly investigate perceived red tape in relation to managers instead of frontline staff (Brewer and Walker 2010b; Pandey, Coursey, and Moynihan 2007). We find that perceived organizational red tape among frontline staff is negatively associated with performance, whereas this is not the case for manager-perceived red tape. This also demonstrates the relevance of considering red tape as a stakeholder concept (Feeney and Bozeman 2009), even when examining the organizational level, as different stakeholders perceive what shapes an organization's performance differently.

This article applies survey data from 142 principals and 2,890 teachers collected from Danish upper secondary schools in December 2012, coupled with an objective, register-based organizational performance measure of effectiveness (school valueadded to student learning). This allows us to test the relationship between perceived organizational red tape among managers and frontline staff and an external, objective measure of performance.

\section{The Literature on Perceived Red Tape and Performance}

In their extensive review of the literature on red tape and organizational performance, Brewer and Walker conclude that "red tape does indeed exert powerful, negative effects on performance, but these effects are not as consistent and uniform as the red tape myth suggests" $(2012,110)$. Their review is based on a small number of studies, however, as the literature is limited. Still, these studies provide a number of important insights and building blocks.

Brewer and Walker's (2010b) study of the impact of red tape among middle managers in English local government is the most comprehensive study of the impact of red tape on performance. They use internal and subjective measures for several performance dimensions alongside an external performance measure combining subjective and objective performance indicators. However, they provide little theoretical argumentation for how and why red tape should affect performance. Empirically, they find a negative aggregate impact of red tape, but it disappears after introducing control variables. Disaggregation of red tape and performance into various dimensions reveals both positive and negative relationships between red tape and performance. In a related study of English local government, Walker and Brewer (2009) find an overall negative relationship between red tape and performance. This relationship is weaker in organizations with prospector stances toward development, unaffected in organizations with defensive and conservative stances, and stronger in organizations with reactive stances that seek to accommodate outside pressures. Thus, the impact of red tape depends on organizational factors that are at least partly within the control of organizational managers.

In the U.S. context, Pandey, Coursey, and Moynihan (2007) study the relationship between red tape and organizational performance as reported by managers. They argue that perceived red tape constrains managerial functions, which, in turn, impedes the organization and hampers performance. In particular, they expect budget-related red tape to reduce financial and managerial capacity; red tape relating to human resource management to limit the ability to motivate and lead the workforce; and red tape associated with information to limit the organization's ability to gather and exchange information. Empirically, they find a negative impact of red tape related to human resources and budgeting but not of information-related red tape. The negative relationship is weaker in organizations with a developmental culture emphasizing an open, positive attitude toward learning and change. This aligns with Walker and Brewer's (2009) results - that a prospector stance reduces the negative impact of red tape. In a related study, Pandey and Moynihan (2006) find that high levels of political support and a developmental culture weaken the negative impact of perceived red tape.

In sum, the existing literature on perceived red tape and performance is characterized by limited theory about the impact of red tape on organizational performance and few empirical tests (Bozeman and Feeney 2011, 115; Brewer and Walker 2012, 120). The studies tend to identify the expected negative relationships, but they are also prone to common-source bias, as performance is not measured objectively but in the surveys, which are also used for measuring perceived red tape.

\section{Why Should Red Tape Perceptions Matter for Performance?}

Organizational performance refers an organization's achievements in relation to a set of standards about its intended goals and achievements (Andersen, Boesen, and Pedersen 2016; O’Toole and Meier 2011). Elected officials and citizens normally expect public organizations to deliver good performance in relation to outputs, service outcomes and effectiveness, efficiency, equity, responsiveness such as user satisfaction, and probity (Boyne 2002). Empirically, this article focuses on effectiveness in the sense of organizations achieving their formal objectives (Boyne 2002, 18) by examining the impact of educational organizations on student learning measured through grades. Stakeholders do not always agree on the salience of various performance dimensions (Andersen, Boesen, and Pedersen 2016), but politically decided goals are prominent in a democratic society.

\section{Perceived Organizational Red Tape}

Policy makers and organizational managers often try to improve performance by engaging in formalization by issuing "rules, regulations, and procedures" (Bozeman and Scott 1996, 8), some of which have implications for the discretion of public employees (Jakobsen and Mortensen 2016). The restriction of discretion is often the intention of policy makers and managers because they expect public employees to otherwise reduce their effort or pursue alternative policy goals (Le Grand 2010). However, the red tape literature emphasizes the persistence of rules that do not serve their purpose. Either they have never had functionality or they have lost whatever functionality they might have had (Bozeman and Feeney 2011). This is the objective element of red tape.

However, the functionality of rules also has a perceived aspect. In his seminal book on the topic, Kaufman noted that "it is people's perceptions of government constraints, not objective measures of reasonableness, that lead them to attack constraints as red tape" 
$(1977,5)$. Following this understanding and that of Pandey and Kingsley $(2000,782)^{1}$ and more recent empirical studies (Pandey, Coursey, and Moynihan 2007; Pandey and Moynihan 2006), we define perceived red tape as the perception that rules and procedures (formalization) in an organization are detrimental to organizational performance. This definition has several positive characteristics.

First, it relates perceived organizational red tape to the negative organizational impact of formal rules. This focus on negative effects is widespread in the red tape literature (Bozeman and Scott 1996, 2; Brewer and Walker 2012, 111; Kaufmann and Feeney 2012, 1197). It follows from Bozeman's canonical definition of red tape as "[r]ules, regulations, and procedures that remain in force and entail a compliance burden for the organization but make no contribution to achieving the rules' functional objectives" $(1993,283)$.

Furthermore, the focus is on organizational performance as opposed to the particular goals of specific stakeholders.

Second, the definition views red tape as a perceptual phenomenon. This is a clear departure from the Bozeman's traditional definition of red tape, which emphasizes the actual burdens of rules irrespective of perceptions. Nonetheless, it is consistent with Kaufman's $(1977,4)$ original understanding of red tape as often differing perceptions of the same rules. One actor can perceive a set of rules as red tape, while another sees them as protecting important values. Furthermore, several key studies of red tape and performance are explicitly based on a perceptual definition of red tape (Pandey, Coursey, and Moynihan 2007; Pandey and Moynihan 2006), and almost all published studies have measured red tape as a perceptual phenomenon rather than measuring the actual, objective functionality of rules (Bozeman and Feeney 2011). ${ }^{2}$ One advantage of the perceptual definition is that it avoids the tautological fallacy of viewing red tape as rules with a negative impact on performance. As long as the definition of red tape embodies negative performance effects, we cannot separate rules from effect; the perceptual definition allows us to do exactly this. The perception that rules hamper performance does not imply that they have actually affected performance negatively. It is possible for people to perceive rules as detrimental to performance even though this is not actually correct.

Third, the definition relates to an entire population of rules regardless of their origins within or outside of the organization or their specific focus (Pandey and Kingsley 2000, 782). The individual rules are not in focus, which allows us to focus on the general perceptions of rules in relation to performance. This does not preclude the relevance of studying specific parts of the rule population, such as perceptions of internally or externally generated red tape (Baldwin 1990), or studying how the rule population is perceived to constrain specific organizational functions, such as human resource management, budgeting, or communication (Pandey and Moynihan 2006; Walker, Boyne, and Brewer 2012, 113-15). Nonetheless, without considering the interplay of the rule with the broader rule population, it is difficult to assess the perceived impact of an individual rule.

\section{Perceived Organizational Red Tape and Organizational Performance}

Most public organizations face multiple principals with ambiguous, often conflicting goals (Lan and Rainey 1992); defining performance therefore becomes controversial. This challenge relates to the stakeholder-based concept of red tape, which focuses on the perceived impact of rules for specific actors (Bozeman and Feeney 2011, 46; Feeney and Bozeman 2009). Given the focus on organizational red tape, we examine the organizational goals of the most important stakeholders in a representative democracy: the political principals. They have strong goals regarding effectiveness in our research setting, and the managers and frontline staff alike share these goals to a relatively high degree (see the section on methods). We also measure perceived organizational red tape through the eyes of two central organizational actors-managers and frontline staffthereby taking into account their diverse perceptions of how rules and procedures affect organizational performance.

Why should a perceived negative impact of formalization on performance lead to negative implications for actual organizational performance? We focus on the managers responsible for running public service organizations and the frontline employees who deliver actual services. Many public organizations deliver complex public services, meaning that the goods are nontangible, consumed at the moment of production, involve some element of coproduction, and cannot be produced without some level of discretion and expertise among frontline staff (Currie and Lockett 2011; Osborne 2013).

In public service organizations operating within complex environments (e.g., schools), the frontline staff (i.e., teachers) play a key role in service production, as discretion and individual professional expertise are needed to execute tasks in direct interaction with the citizens (i.e., students). This requires independent frontline personnel who are able to work without controlled regulation (Mintzberg 1996; Vandenabeele 2007) and who have the expertise and opportunity to deliver good performance (Ouchi 1980). Public service organizations such as schools would most likely perform poorly if frontline employees were prevented from exercising their expertise and autonomy, which could also significantly reduce their motivation.

Public managers must ensure that their organizations are able to deliver high performance. This can be achieved through strategic stances by which an organization either proactively or defensively tries to develop by changing markets and services, changing the relationship with external stakeholders, or by introducing new processes and systems to the organization (Boyne and Walker 2004). Managers can also seek to influence frontline staff by either emphasizing the organization's vision (Moynihan, Pandey, and Wright 2012; Wright, Moynihan, and Pandey 2012) or involving staff in decisions (Mikkelsen, Jacobsen, and Andersen 2017). In public service organizations, this managerial impact on performance predominantly takes place through the practice of frontline staff and therefore is less direct than the impact of the frontline staff themselves.

The key issue is how the perception of a detrimental impact from formalization-organizational red tape-is likely to constrain and motivate organizational frontline staff and managers in a manner that affects organizational performance. A key distinction is between constraining and motivational mechanisms.

The constraining mechanism operates when managers and frontline staff perceive that constraints affect their behavioral choices 
(DeHart-Davis and Pandey 2005), such as whether or not to change their work practices. The constraining effect of red tape is central in the red tape literature on performance, where it can constrain managers in relation to promoting employee motivation because of human resources red tape or redistributing resources because of financial red tape (Pandey, Coursey, and Moynihan 2007; Pandey and Moynihan 2006). Similarly, perceived red tape can constrain frontline staff behavior, as in relation to the choice and adjustment of teaching methods within education, which are important factors in student learning (Andersen and Andersen 2015; Hattie 2008).

The motivational mechanism arises because a perceived detrimental impact of the rule environment is likely to have a negative impact on motivation (Jacobsen, Hvitved, and Andersen 2014). This argument rests on social psychological research that has shown subjective experiences of selfdetermination to be important for maintaining employee motivation (Deci, Koestner, and Ryan 1999; Ryan and Deci 2000). This research has also generally supported the notion that autonomy-supportive work environments promote employee self-determination, autonomous motivation, and employee effort (Gagné and Deci 2005).

Specifically in relation to the public sector, Moynihan and Pandey find that red tape "discourages employees from believing they are serving the public good" $(2007,47)$ and they find negative relationships between red tape and some dimensions of public service motivation. DeHart-Davis and Pandey (2005) find that red tape reduces opportunities for development and expression, which is found to be negatively related to motivation, commitment, and satisfaction. Hjelmar, Pedersen, and Bordacconi $(2013,38)$ also find red tape to be negatively related with autonomous motivation among Danish public employees. Perceived red tape can be expected to reduce autonomous motivation, which has again been shown to hurt the teaching effects of individual teachers on students (Andersen, Heinesen, and Pedersen 2014). We thus formulate the following hypothesis:

Performance hypothesis: The higher the level of perceived organizational red tape, the lower the level of organizational performance.

\section{Frontline Staff versus Managers}

A distinction must be drawn between managers and frontline employees when assessing how red tape perceptions affect performance. Walker and Brewer (2008) find that red tape perceptions decrease with the hierarchical level and that different determinants matter for red tape perceptions across hierarchical levels. Thus, perceptions of red tape can diverge because managers and employees have different perspectives and means-ends beliefs about how to achieve performance and because they attend to different parts of the rule environment. Managers focus more on broader organizational aspects, whereas frontline employees primarily focus on their specific tasks. Studies have also suggested that different groups of managers or occupational groups with common interests and functions have very different red tape perceptions (Brewer and Walker 2010a), and perceived red tape for one group therefore may also affect performance differently than for another group. In organizations in which the frontline employees are professionals with greater discretion and importance for service production, managerperceived red tape matters less for performance than frontline-perceived red tape. One example is schools, where teachers must apply their professional expertise with discretion in order to select and adapt teaching techniques or assessment procedures to improve learning outcomes. The impact of managers would

have to pass through this level to affect performance. This makes the impact of manager-perceived red tape weaker and more indirect. This brings us to the following hypothesis:

Manager-staff hypothesis: The performance impact of perceived red tape is stronger among frontline staff than among managers.

\section{Research Design}

The data for this study are based on two questionnaires sent to principals and teachers at 148 publicly owned and funded Danish secondary schools in December 2012. The study focuses on secondary schools, which allows us to control for potentially disturbing institutional factors by holding them constant. The schools are subject to the same regulations, the employees are highly similar, and the schools can be assessed on the same aspects of performance. In order to focus on similar organizations, our study is limited to upper secondary education, which comprises three programs in the Danish system: (1) the General Upper Secondary Education Program (STX), (2) the Higher Commercial Examination Program (HHX), and (3) the Higher Technical Examination Program (HTX). These educational institutions provide nationally regulated, tuition-free general education to the majority of Danish youth (Danish Ministry of Education 2015). These schools are selfgoverning institutions financed by activity-based reimbursements from the central government (e.g., based on passed exams and student graduation). The school principals are accountable to school boards, which report to the Ministry of Education.

Formal rules from the central government and collective bargaining are important for service provision in secondary schools, and the number of rules has been growing in recent decades (see figure 1 for the increase in the number of rules over a 20-year period). The figure is based on a tally of the number of sentences (here an operationalization of rules) in Danish laws with relevance for upper secondary institutions. This approach has also been used to study Dutch universities, Danish primary schools, and other public institutions (Jakobsen and Mortensen 2016; Kaufmann and van Witteloostuijn 2012; Van Witteloostuijn and de Jong 2010), and it provides an objective measure of the density of lawmaking at a given point in time.

Most of this increase in formalization is associated with two "jumps" in rulemaking (1991-92 and 2004-05) resulting from two major 


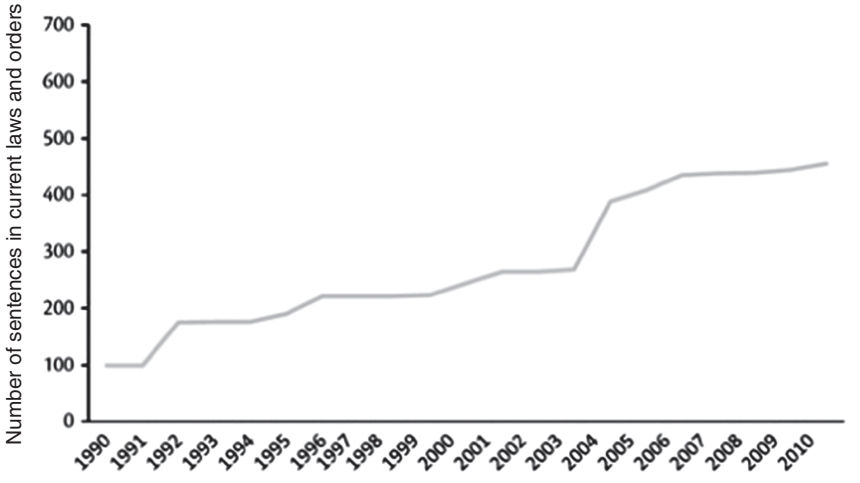

Figure 1 Growth in Rulemaking over Time (Number of Sentences in Danish Laws Governing Upper Secondary Education)

reforms focused on education procedures, exams, and organization. The 2005 reform targeted education administration, course content, and examinations, all of which affected the teachers' work. Other rules were adopted in 2008, when authority over the STX schools was transferred from the counties to self-government under state authority. This reform substantially increased school autonomy and gave principals a more clearly defined role as school managers. Thus, overall, perceived red tape in Danish upper secondary schools should be interpreted in the context of increased rulemaking in recent years, much of which has been directed at tasks and procedures for the teachers, while school principals have obtained more autonomy. This interpretation is supported by similar developments in the executive orders issued by the minister of education during the same period (Jakobsen and Mortensen 2014). The rule environment can still differ among schools, however, as local boards and principals as well as local collective agreements with unions can produce specific rules and regulations.

\section{Data}

We obtained contact information for principals and all of the teachers at 148 upper secondary schools. Thirty-four other schools either declined to participate or did not make contact information available. In order to address concerns of nonparticipation bias, we compared the participating and nonparticipating schools and found that they are not statistically significantly different in relation to size, performance (school value-added, measured as expected grade levels based on social demographics minus observed grade levels), budget size, competition (number of secondary schools within 10 kilometers), geographic location (rural versus urban), principal age, or gender.

Questionnaires were sent to all 8,859 teachers in the participating schools in late November 2012. Of these, 341 email addresses were not valid, and 48 teachers declined to participate. We sent out three reminders over three weeks and received 2,890 useful responses in total (34.1 percent response rate) from the 148 schools. Ninetysix principals (58.2 percent) completed the relevant sections of the survey. Because the relatively low teacher response rate, our sample may not be representative of the population of teachers. Nonetheless, based on observed variables, we find no differences between the population of teachers and our sample regarding age, gender, or subject (natural sciences versus other subjects). We use the 142 schools for which we have present and past performance data (because some schools were reorganized in the period of study, we lack access to past performance data for a limited number of schools). Performance data were combined with survey data from the 2,890 teachers at the 142 schools and used in the analysis. Another combined teacher-principal data set covers 90 schools (with performance data) in which the principals responded, as well as the 1,952 teachers at these schools.

\section{Measures}

All of the variables in the study except performance were measured using questionnaires. We used parallel questionnaires for teachers and principals, with identical questions relating to perceived red tape and individual background information. Defining red tape as perceptual, we measure how principals and teachers perceive the rules and procedures related to their work as burdensome and as a hindrance to effective service delivery. The red tape survey questions relate to the execution of organizational tasks as opposed to the impact of the rule population on the interests of specific stakeholders, such as users, managers, or trade unions. We used items from a recently developed multi-item measurement instrument that focuses on how rules and procedures are perceived to make the work environment more troublesome, timeconsuming, and hindering the obtainment of actual purposes (Hjelmar, Pedersen, and Bordacconi 2013). The measure therefore has high face validity, as it is taps into central aspects of the most widely applied understandings of red tape (Bozeman and

Feeney 2011). The items also closely resemble key items in the newly validated red tape scales from Van Loon et al. $(2016,673)$ in relation to time consumption, delays, and contributions to achieving goals (although this scale is two-dimensional in contrast to ours).

Respondents were asked to rate their agreement or disagreement with each of three statements on a five-point Likert scale (ranging from "totally disagree" to "totally agree"). A factor analysis (principal axis factor analysis) shows that the three-item measurement models at both the principal and teacher levels indicate consistent and strong fits (see table A1 in the appendix). Among the 90 principals, loadings for the three items are high (between 0.70 and 0.83 ). However, the fit indices show strong fit, and the Cronbach's alpha score of 0.87 supports the notion that reliability is high. Among the 2,890 teachers, loadings range between 0.75 and 0.85 , the models show a strong fit, and a Cronbach's alpha score of 0.85 supports the notion that reliability is high. The perceived red tape variables for teachers and principals are additive indices, each based on three items scaled from 0 to 15 ( 0 indicating minimum perceived red tape). In order to test convergent validity, we correlate our measure with the GRT (General Red Tape) scale ("If red tape is defined as burdensome administrative rules and procedures that have negative effects on the organization's effectiveness, how would you assess the level of red tape in your organization?," scale $0-10$ ). The GRT has been argued to be compatible with the theoretical definition of 
red tape (Pandey and Scott 2002, 563) and has been used in many red tape studies (Bozeman and Feeney 2011, 84). We find strong correlations (Pearson's $r=0.70$ for teachers and 0.61 for principals) between our red tape measure and the GRT. The results are similar when running all analyses using both the GRT scale and our latent scale.

Despite the uniformity of the rules directed at upper secondary schools, the principals perceive red tape differently. For the 90 principals, the perceived red tape index ranges from very low levels of perceived red tape ( 4 on the 3-15 scale) to the highest perceived level of red tape $(\max =15)\left(\right.$ mean $\left._{\text {principal }}=8.5\right)$. There is also considerable variation among teachers perceptions of red tape varying over the full scale at the individual teacher level. Given that we study perceived red tape and organizational performance, we aggregate the teacher-perceived red tape at the school level, and these aggregated teacher perceptions of red tape range between 5.9 and $11.3\left(\right.$ mean $\left._{\text {teachers school }}=9.0\right)$ at the 142 schools. The difference between principal- and teacher-perceived red tape at the 90 schools with principal responses is significant at the 0.05 level $(p=.014)$, indicating that, on average, teachers perceive higher levels of red tape than principals. Furthermore, the two measures are uncorrelated (Pearson's correlations), which implies that managers and employees in the same organization perceive red tape very differently and that they focus on different aspects of rulemaking. This also reveals the importance of studying manager- and employee-perceived organizational red tape separately, as they are likely to have different antecedents and consequences.

The dependent variable, organizational performance, is measured as school value-added to student learning. This variable measures the extra value in terms of effectiveness (student grades) that the schools provide given the preconditions of their users and allows us to address several calls to employ objective conceptualizations of performance in studies of organizational performance (Walker, Boyne, and Brewer 2012). Using grades as a performance outcome is useful for a number of reasons. First, grades offer a comparable standard of school outcomes across the selected schools. Second, we only use externally graded written exams, as these measures are beyond the control of the teachers and managers who are used to measure the independent variable of perceived red tape. These institutionalized assessments considerably reduce concerns of common-source bias (Andersen, Heinesen, and Pedersen 2016). The measures were obtained from Statistics Denmark, which collects exam grade data for all Danish upper secondary school students. School value-added (performance) was calculated only for written, externally graded exams in order to avoid confounding of effects. It was calculated using multilevel models with controls for school and student characteristics (a number of sociodemographic variables, including gender, birth year, parents' level of education, parents' income [in Danish krone], parents' employment, parents' age, and ethnicity) that are known to be important predictors of grades (Wittrup 2015). We have data on performance from 142 schools with at least five teacher survey responses and 90 schools in which both the principal and at least five teachers responded.

Several control variables were collected using the surveys. All teacher-level variables were calculated as means for a given school.
At the teacher level, the subjects they taught were coded into broad areas (science/nonscience), so we controlled for the share of science and nonscience teachers among the respondents. We controlled for the teachers' average number of subjects at a school because a greater number of subjects reflects broader tasks, which might reflect more perceived red tape. Experience in general and with a specific organization could be associated with perceptions of red tape, and therefore we controlled for mean age and tenure. We controlled for gender composition despite nonfindings at the individual level (Feeney and DeHart-Davis 2009) because gender might function differently at the organizational level. We also controlled for the share of part-time employment and the unionization rate.

At the school level, we controlled for school size because perceived red tape has been found to be more prevalent in larger organizations (Pandey and Kingsley 2000). Mainly for control purposes, we also controlled for principal age, principal tenure, and principal gender. Finally, and perhaps most importantly, we controlled for past performance by introducing a lagged performance measure to take the autoregressive nature of performance into account (Meier and O'Toole 1999). In the appendix, table A2 shows descriptive statistics regarding all of the variables used in the study, and table A3 shows a correlation matrix between all of the examined variables for schools with teacher and principal responses. The table shows that the bivariate correlations between both teachers' and managers' perceptions of red tape are negatively but insignificantly correlated with school performance. However, the multivariate regressions will show how this changes when the control variables are introduced.

\section{Methods}

As mentioned earlier, the data set includes information from surveys of teachers and principals. In order to utilize the full data set, we first show analyses for all of the 142 schools with teacher responses. Principals from 52 of these schools did not respond to the survey, so in order to test the importance of principals' perceived red tape, we ran separate analyses for the 90 schools with both teacher and principal responses. The unit of analysis in all of the analyses is the school, so all of the measures have been aggregated at the school level. We use ordinary least squares (OLS) regression and study how teacher- and principal-perceived red tape relates to performance outcomes. We have made extensive stepwise regressions with the control variables (not reported), which show that the key results are stable across the models.

\section{Analysis}

First, table 1 shows how employee-perceived organizational red tape and the control variables are related to performance for all schools. The table shows an OLS regression for the 142 schools with teacher responses (we return to analyses of the 90 schools with both teacher and principal responses later), and model 1.1 shows that, as expected, teacher red tape is negatively related to organizational performance $(p<.1)$. Controlling for lagged performance (model $1.2)$ only strengthens the importance of perceived red tape. The coefficient of the perceived red tape measure is -0.0101 , which is the reduction in grade-point average expected from one extra point of perceived red tape (scaled 0-100). Given that the standard deviation of organizational performance is 0.071 and the standard deviation of perceived red tape is 0.99 , a one standard deviation increase on the perceived red tape scale is associated with a 0.19 
Table 1 OLS Regression of School Performance-All Schools, Overall Grades (Written, Externally Graded Exams)

\begin{tabular}{|c|c|c|}
\hline & Model 1.1 & Model 1.2 \\
\hline Perceived red tape, teachers & $\begin{array}{l}-0.0101+ \\
(-1.75)\end{array}$ & $\begin{array}{l}-0.0120 * \\
(-2.51)\end{array}$ \\
\hline Teachers' mean age (years) & $\begin{array}{l}-0.0101+ \\
(-1.75)\end{array}$ & $\begin{array}{l}-0.0120 * \\
(-2.51)\end{array}$ \\
\hline Teachers' mean tenure (years) & $\begin{array}{l}0.00922 * * \\
(3.15)\end{array}$ & $\begin{array}{l}0.00540 * \\
(2.59)\end{array}$ \\
\hline$\%$ male teachers & $\begin{array}{l}-0.0280 \\
(-0.68)\end{array}$ & $\begin{array}{l}0.00688 \\
(0.20)\end{array}$ \\
\hline$\%$ part-time employed & $\begin{array}{l}-0.0525 \\
(-0.84)\end{array}$ & $\begin{array}{l}-0.0913+ \\
(-1.97)\end{array}$ \\
\hline$\%$ science teachers & $\begin{array}{l}-0.0647 \\
(-1.02)\end{array}$ & $\begin{array}{l}-0.0658 \\
(-1.35)\end{array}$ \\
\hline Teachers' mean number of subjects & $\begin{array}{l}-0.0310 \\
(-1.14)\end{array}$ & $\begin{array}{l}-0.0253 \\
(-1.52)\end{array}$ \\
\hline$\%$ unionized teachers & $\begin{array}{l}0.184+ \\
(1.89)\end{array}$ & $\begin{array}{l}0.186^{*} \\
(2.25)\end{array}$ \\
\hline School size (no. of teachers) & $\begin{array}{l}-0.000342 \\
(-1.58)\end{array}$ & $\begin{array}{l}-0.000179 \\
(-1.15)\end{array}$ \\
\hline \multicolumn{3}{|c|}{ Degree type (ref: Business upper secondary school) } \\
\hline General upper secondary school & $\begin{array}{l}-0.0147 \\
(-0.62)\end{array}$ & $\begin{array}{l}-0.00249 \\
(-0.14)\end{array}$ \\
\hline Technical upper secondary school & $\begin{array}{l}0.0737 \\
(1.57)\end{array}$ & $\begin{array}{l}0.0274 \\
(0.82)\end{array}$ \\
\hline Lagged school performance & & $\begin{array}{l}0.539 * * * \\
(10.12)\end{array}$ \\
\hline Constant & $\begin{array}{l}0.304+ \\
(1.97)\end{array}$ & $\begin{array}{c}0.159 \\
(1.28)\end{array}$ \\
\hline$N$ & 142 & 142 \\
\hline Adjusted $R^{2}$ & 0.098 & 0.474 \\
\hline
\end{tabular}

Note: $t$-statistics in parentheses.

$+p<.1 ;{ }^{*} p<.05 ; * * p<.01 ; * * * p<.001$

standard deviation decrease in school performance. This coefficient is large enough to be substantially interesting, but considering how problematic red tape is often portrayed to be, a stronger relationship might have been expected.

A number of control variables are also statistically significantly related to performance. For instance, teacher tenure is strongly and positively related to performance, whereas teacher age is negatively related to performance. Given that we control for both variables, age should be interpreted here as the age at the time of entry into the organization. The negative coefficient probably means that in a sector with relatively low job turnover, older teachers are more likely to change jobs when they are low performers or they switch to already low-performing schools. Larger schools produce worse results than expected, but this should not necessarily be interpreted as a causal effect; larger schools could be populated by students with unobserved characteristics with negative implications for learning. Finally, there is some variation between programs, but this might be attributable to unobserved variables. Generally speaking, performance is not explained much by the control variables when we control for lagged performance, and only teacher mean age, tenure, and unionization remain significant.

Turning to table 2, the negative implications of teachers' perceived red tape on performance are also found when we control for the principals' perceived red tape at the 90 schools with principal responses. The coefficient size at these schools is somewhat greater $(-0.0142$ in the final model) than at all schools (table 1$)$. However, the principals' perceptions are not significantly related to performance (this may be related to statistical power). After controlling for principal-perceived red tape and lagged performance, a one standard deviation change on the teacher-perceived red tape scale is expected to change school value-added to grades by approximately 0.23 standard deviations. Although the relationship is stronger than found at all of the schools under study, it is still weaker than other studies suggest. The control variables show more or less the same relationships with exam grades as in table 1.

\section{Discussion}

We have argued that perceived organizational red tape affects performance negatively in public service organizations with frontline staff who have high levels of discretion, expertise, and autonomous motivation. Furthermore, we argued that the organizational red tape perceived by frontline staff in such organizations has a greater impact on performance than organizational red tape perceived by managers. Empirically, the performance hypothesis was supported by the finding of a negative relationship between employee-perceived organizational red tape and performance. Although the coefficient for the managerperceived red tape was also negative, it was not significant. Moreover, the results suggest that the relationship between employee-perceived organizational red tape and organizational performance is weaker than suggested in prior studies that did not use external and objective performance measures or control for prior levels of performance. One explanation for this finding is that common-source bias does not inflate the relationship between perceived red tape and performance in this study and that the actual relationship between perceived red tape and organizational performance is weaker than previously believed. Furthermore, as expected by the manager-staff hypothesis, only employeeperceived red tape is negatively associated with organizational performance, whereas manager-perceived red tape is unrelated to performance.

We studied one indicator of school performance capturing effectiveness (i.e., school value-added to student learning). This performance dimension is a key factor for schools, but other dimensions of performance, such as equity and value for money, certainly are also relevant. Based on the theoretical framework, we expect our findings to be relevant for other aspects of performance as well, but previous studies have suggested that red tape may not be uniformly related to different dimensions of performance. For example, one study found that red tape was related to equity and quality but unrelated to value for money (Brewer and Walker 2010b). Applying other objectively measured dimensions of performance in future studies would help add nuance to our understanding of red tape effects by either replicating previous findings or revealing new and surprising patterns.

Some limitations to this study should be noted. First, the study focused on secondary schools in Denmark because they are highly comparable in terms of general rulemaking and performance indicators. We were thus able to study how varying red tape perceptions relate to performance. We believe that these findings produce knowledge of more general relevance, but this choice also requires caution when generalizing the results beyond the school sector and outside Denmark. The school sector is relatively comparable across countries, and many other public service 


\begin{tabular}{|c|c|c|c|c|}
\hline & Model 2.1 & Model 2.2 & Model 2.3 & Model 2.4 \\
\hline Perceived red tape, teachers & $\begin{array}{l}-0.0193 * * \\
(-2.69)\end{array}$ & & $\begin{array}{l}-0.0195 * * \\
(-2.75)\end{array}$ & $\begin{array}{l}-0.0142 * \\
(-2.41)\end{array}$ \\
\hline Perceived red tape, principal & & $\begin{array}{l}-0.00256 \\
(-0.78)\end{array}$ & $\begin{array}{l}-0.00275 \\
(-0.83)\end{array}$ & $\begin{array}{l}-0.00226 \\
(-0.90)\end{array}$ \\
\hline Teachers' mean age (years) & $\begin{array}{l}-0.00944+ \\
(-1.96)\end{array}$ & $\begin{array}{l}-0.00887+ \\
(-1.81)\end{array}$ & $\begin{array}{l}-0.00881+ \\
(-1.77)\end{array}$ & $\begin{array}{l}-0.00454 \\
(-1.24)\end{array}$ \\
\hline Teachers' mean tenure (years) & $\begin{array}{l}0.00812 * \\
(2.14)\end{array}$ & $\begin{array}{l}0.00771 \text { * } \\
(2.02)\end{array}$ & $\begin{array}{l}0.00782 \text { * } \\
(2.06)\end{array}$ & $\begin{array}{l}0.00489+ \\
(1.77)\end{array}$ \\
\hline$\%$ male teachers & $\begin{array}{l}-0.0205 \\
(-0.45)\end{array}$ & $\begin{array}{l}0.00192 \\
(0.04)\end{array}$ & $\begin{array}{l}-0.0208 \\
(-0.44)\end{array}$ & $\begin{array}{l}-0.00312 \\
(-0.08)\end{array}$ \\
\hline \% part-time employed & $\begin{array}{l}-0.103 \\
(-1.31)\end{array}$ & $\begin{array}{l}-0.0813 \\
(-1.01)\end{array}$ & $\begin{array}{l}-0.0988 \\
(-1.29)\end{array}$ & $\begin{array}{l}-0.0973+ \\
(-1.74)\end{array}$ \\
\hline$\%$ science teachers & $\begin{array}{l}-0.0506 \\
(-0.73)\end{array}$ & $\begin{array}{l}-0.0522 \\
(-0.69)\end{array}$ & $\begin{array}{l}-0.0546 \\
(-0.76)\end{array}$ & $\begin{array}{l}-0.0462 \\
(-0.76)\end{array}$ \\
\hline Teachers' mean number of subjects & $\begin{array}{l}-0.0502 \\
(-1.66)\end{array}$ & $\begin{array}{l}-0.0611+ \\
(-1.85)\end{array}$ & $\begin{array}{l}-0.0527+ \\
(-1.69)\end{array}$ & $\begin{array}{l}-0.0351 \\
(-1.50)\end{array}$ \\
\hline$\%$ unionized teachers & $\begin{array}{l}0.408 * * \\
(3.04)\end{array}$ & $\begin{array}{l}0.339 * \\
(2.64)\end{array}$ & $\begin{array}{l}0.415 * * \\
(3.16)\end{array}$ & $\begin{array}{l}0.237^{*} \\
(2.09)\end{array}$ \\
\hline Principal gender $($ male $=1)$ & $\begin{array}{l}0.00742 \\
(0.41)\end{array}$ & $\begin{array}{l}0.00574 \\
(0.29)\end{array}$ & $\begin{array}{l}0.00497 \\
(0.27)\end{array}$ & $\begin{array}{l}0.00707 \\
(0.54)\end{array}$ \\
\hline Principal tenure (years) & $\begin{array}{l}0.00307 * * \\
(3.19)\end{array}$ & $\begin{array}{l}0.00323 * * \\
(3.15)\end{array}$ & $\begin{array}{l}0.00297 * * \\
(2.93)\end{array}$ & $\begin{array}{l}0.00126 \\
(1.49)\end{array}$ \\
\hline School size (no. of teachers) & $\begin{array}{l}-0.000523 * \\
(-2.00)\end{array}$ & $\begin{array}{l}-0.000546+ \\
(-1.99)\end{array}$ & $\begin{array}{l}-0.000517+ \\
(-1.96)\end{array}$ & $\begin{array}{l}-0.000320 \\
(-1.59)\end{array}$ \\
\hline \multicolumn{5}{|c|}{ Degree type (ref: Business upper secondary school) } \\
\hline General upper secondary school & $\begin{array}{l}-0.0369 \\
(-1.28)\end{array}$ & $\begin{array}{l}-0.0406 \\
(-1.38)\end{array}$ & $\begin{array}{l}-0.0381 \\
(-1.31)\end{array}$ & $\begin{array}{l}-0.0141 \\
(-0.64)\end{array}$ \\
\hline Technical upper secondary school & $\begin{array}{l}0.130 * \\
(2.12)\end{array}$ & $\begin{array}{c}0.113 \\
(1.62)\end{array}$ & $\begin{array}{l}0.128 * \\
(2.00)\end{array}$ & $\begin{array}{l}0.0521 \\
(1.05)\end{array}$ \\
\hline Lagged school performance & & & & $\begin{array}{l}0.562 * * * \\
(8.47)\end{array}$ \\
\hline Constant & $\begin{array}{c}0.236 \\
(1.04)\end{array}$ & $\begin{array}{c}0.189 \\
(0.80)\end{array}$ & $\begin{array}{c}0.225 \\
(0.98)\end{array}$ & $\begin{array}{c}0.137 \\
(0.74)\end{array}$ \\
\hline$N$ & 90 & 90 & 90 & 90 \\
\hline Adjusted $R^{2}$ & 0.225 & 0.174 & 0.224 & 0.532 \\
\hline
\end{tabular}

Note: $t$-statistics in parentheses.

$+p<.1 ;{ }^{*} p<.05 ;{ }^{* *} p<.01 ; * * * p<.001$.

organizations (e.g., hospitals) share central characteristics with schools (O’Toole and Meier 2011, 45), particularly in terms of frontline staff with expertise and autonomous motivation and direct interaction with citizens.

Nonetheless, there is a need for further studies that investigate the broader relevance of perceived red tape on organizational performance. We have hypothesized about and studied this relationship in professionalized, complex public service organizations. Thus, we can expect our results to be relevant for public service organizations with autonomously motivated employees, but how relevant are they in other types of public organizations?

Contingency theory suggests that a lack of fit between internal components and the environment produces lower performance (Donaldson 2006; Mintzberg 1979, 220), which points out the scope conditions of the article's argument. Schoolteachers operate within complex environments based on discretion and professional expertise, and schools have traditionally been governed as professional bureaucracies based on the standardization of skills and the socialization of teachers (Mintzberg 1979; Wilson 2000).
Hence, discretion and autonomy have been bestowed on teachers assuming that they are autonomously motivated to perform without controlled regulation (Mintzberg 1996; Vandenabeele 2007). In such areas, as argued in theory, red tape perceptions can challenge autonomous motivation if it "discourages employees from believing they are serving the public good" (Moynihan and Pandey 2007, 47) and thereby be detrimental to performance.

For simple, technical services such as garbage collection, however, task execution requires much less discretion, and it is easier to supervise behaviors and results than in complex environments (Mintzberg 1979). Such services do not require high levels of autonomous motivation because it is easier to motivate employees through regulations. To the extent that the negative effects of red tape are motivational, red tape perceptions therefore must be expected to be more detrimental to performance in complex environments than in simple, technical services.

Red tape theory originally focused on administrative employees. Autonomous motivation such as public service motivation has also been found to play an important role in this area (Ritz 2009), which 
implies that perceived red tape could also have a negative impact in the administrative arena. On the contrary, red tape could be argued to play a different role in a rule-driven environment (e.g., administration) than in service areas. Thus, administrative employees may be more understanding and accepting of rules and regulations, which is also signified by their attraction to engage in policy making (Perry, Hondeghem, and Wise 2010). Thus, it would be fruitful if empirical studies could shed more light on this question, although objective and observable performance data might be difficult to obtain. It also calls for more theorizing about the contingencies of perceived red tape in organizations. In general, we would broadly expect to find conditional effects, where perceived red tape is expected to have a different impact on performance depending on, for example, levels of autonomous motivation and the need for expertise.

Another limitation relates to the question of causality. Despite the negative association between employee-perceived red tape and organizational effectiveness, we cannot be certain that perceived red tape is lowering performance. Given the cross-sectional design (with an appropriate time lag) applied in this study, two serious concerns could be that the causal direction is reversed or that the relationship is caused by unobserved, omitted variables. In relation to reverse causality, poor school performance could cause perceived red tape if red tape perceptions followed from performance pressure, especially in low-performing schools. In this case, red tape perceptions would be explained by prior performance. We took this argument into consideration by controlling for past performance, and the results proved to be robust to this control. This indicates that reverse causality bias is at least not a severe concern in this study. We also believe that the use of value-added grades rather than observed grades reduces the concern for reverse causality bias. Although value-added measures have gained importance in the Danish school system in recent years, schools are (and certainly were in 2012, when this data set was collected) mainly held accountable for raw observed performance measures not taking into account the socioeconomic background of students. Thus, returning to the rule-production argument, this would be expected to be driven more by observed performance levels than by value-added performance measures.

The other concern is omitted variable bias, which cannot be ruled out because of the cross-sectional research design. Nonetheless, we have tried to take this into consideration as much as possible by controlling for variables that are otherwise known to be related to organizational performance. Although it will be challenging, future studies should provide knowledge on red tape effects by conducting panel studies with variation in perceived red tape and performance over time or experimental designs with random assignments of rules expected to induce random variations in perceived red tape. Such approaches would generally alleviate the aforementioned concerns related to common-source bias, unobserved variables bias, and reverse causality.

Finally, we focus on perceived red tape but not on formal rules, as otherwise theorized in classical red tape theory. As argued earlier, however, the fallacy of classical red tape theory is one of tautology-how can we study the detrimental effects of rules which are already defined as lacking functionality? Therefore, we have also suggested that the literature should focus on perceived red tape, which has long been the actual area of study given that most empirical red tape studies have not examined rules but rather perceptions of rules. We have also shown that within organizations, perceptions of red tape vary markedly, and perceptions between schools also differ despite facing the same general rules and regulations. This may be partly attributable to variations in internal rulemaking, but the principals who are confronted with the same set of nationally devised rules also differ markedly in their perceptions. Actual rulemaking may affect performance-perhaps much more than the limited importance we have found of perceived red tape-but we urge scholars to further consider how we can study these effects without assuming them to be negative. This directs attention to the red tape concept, which we are not the first to point to as problematic for effect studies (Bozeman and Feeney 2011). In operational terms, this also necessitates direct measures of actual red tape, which is much more difficult than studying perceptions. Furthermore, we still lack knowledge on the relationship between actual rulemaking and perceptions of red tape, but studies have already shown that objective formalization and perceived red tape can be weakly related (Kaufman and Feeney 2012). Hence, studying perceptions of red tape in their own right would probably be fruitful.

\section{Conclusion and Perspectives}

The purpose of this article was to add to our theoretical and empirical knowledge concerning the relationship between perceived red tape and performance. We found that in the schools under investigation, teacher perceptions of red tape- but not manager perceptions of red tape-relate negatively to school performance, although this relationship is relatively weak. This is despite the fact that teachers are generally autonomously motivated and used to high levels of discretion and therefore potentially susceptible to motivation crowding if they perceive the regulatory environment to be constraining.

Despite the provisional nature of these conclusions, some general implications for management and governance follow from the analysis. The widespread belief that perceived red tape is a substantial constraint on public sector performance is not supported, and leaders and policy makers should avoid placing too much faith in the reduction of perceived red tape as their main strategy for performance improvement. In particular, such a strategy should be pursued only based on a judgment as to whether perceived red tape in an organization is substantially hampering performance. If a strategy of perceived red tape reduction-or mitigation of its negative consequences—is pursued, managers and policy makers should be aware that perceived red tape involves perceptions that only partially reflect actual formalization. Leadership in terms of setting goals, involvement, and proactive stances is known to reduce or mitigate the impact of red tape (Mikkelsen, Jacobsen, and Andersen 2017; Walker and Brewer 2009) and could play a key role in reducing it. 


\section{Notes}

1. Pandey and Kingsley define red tape as "impressions on the part of managers that formalization (in the form of burdensome rules and procedures) is detrimental to the organization" $(2000,782)$.

2. Although they use an objective understanding of red tape, many other studies also measure red tape using survey questions that entail a high degree of perception (Bozeman and Feeney 2011; Brewer and Walker 2012, 114).

\section{References}

Andersen, Ida Gran, and Simon Calmar Andersen. 2015. Student-Centered Instruction and Academic Achievement: Linking Mechanisms of Educational Inequality to Schools' Instructional Strategy. British Journal of Sociology of Education 38(4): 533-50.

Andersen, Lotte Bøgh, Andreas Boesen, and Lene Holm Pedersen. 2016. Performance in Public Organizations: Clarifying the Conceptual Space. Public Administration Review 76(6): 852-62.

Andersen, Lotte Bøgh, Eskild Heinesen, and Lene Holm Pedersen. 2014. How Does Public Service Motivation among Teachers Affect Student Performance in Schools? Journal of Public Administration Research and Theory 24(3): 651-71.

2016. Individual Performance: From Common Source Bias to Institutionalized Assessment. Journal of Public Administration Research and Theory 26(1): 63-78.

Baldwin, J. Norman. 1990. Perceptions of Public versus Private Sector Personnel and Informal Red Tape: Their Impact on Motivation. American Review of Public Administration 20(1): 7-28.

Boyne, George A. 2002. Theme: Local Government: Concepts and Indicators of Local Authority Performance: An Evaluation of the Statutory Frameworks in England and Wales. Public Money and Management 22(2): 17-24.

Boyne, George A., and Richard M. Walker. 2004. Strategy Content and Public Service Organizations. Journal of Public Administration Research and Theory 14(2): 231-52.

Bozeman, Barry. 1993. A Theory of Government Red Tape. Journal of Public Administration Research and Theory 3(3): 273-304.

Bozeman, Barry, and Mary K. Feeney. 2011. Rules and Red Tape: A Prism for Public Administration Theory and Research. Armonk, NY: M. E. Sharpe.

Bozeman, Barry, and Patrick Scott. 1996. Bureaucratic Red Tape and Formalization: Untangling Conceptual Knots. American Review of Public Administration 26(1): $1-17$.

Brewer, Gene A., and Richard M. Walker. 2010a. Explaining Variation in Perceptions of Red Tape: A Professionalism-Marketization Model. Public Administration 88(2): 418-38.

2010b. The Impact of Red Tape on Governmental Performance: An Empirical Analysis. Journal of Public Administration Research and Theory 20(1): 233-57.

2012. Red Tape: The Bane of Public Organizations? In Public Management and Performance: Research Directions, edited by Richard M. Walker, George A. Boyne, and Gene A. Brewer, 110-26. Cambridge: Cambridge University Press.

Currie, Graeme, and Andy Lockett. 2011. Distributing Leadership in Health and Social Care: Concertive, Conjoint or Collective? International Journal of Management Review 13(3): 286-300.

Danish Ministry of Education. 2015. Upper Secondary Education. http://eng.uvm. $\mathrm{dk} /$ Education/Upper-secondary-education [accessed May 6, 2016].

Deci, Edward L., Richard Koestner, and Richard M. Ryan. 1999. A Meta-Analytic Review of Experiments Examining the Effects of Extrinsic Rewards on Intrinsic Motivation. Psychological Bulletin 125(6): 627-68.

DeHart-Davis, Leisha, and Sanjay K. Pandey. 2005. Red Tape and Public Employees: Does Perceived Rule Dysfunction Alienate Managers? Journal of Public Administration Research and Theory 15(1): 133-48.
Donaldson, Lex. 2006. The Contingency Theory of Organizational Design: Challenges and Opportunities. In Organization Design, edited by Richard M. Burton, Dorthe Døjbak Håkonsson, Bo Eriksen, and Charles C. Snow, 19-40. New York: Springer.

Favero, Nathan, and Justin B. Bullock. 2015. How (Not) to Solve the Problem: An Evaluation of Scholarly Responses to Common Source Bias. Journal of Public Administration Research and Theory 25(1): 285-308.

Feeney, Mary K., and Barry Bozeman. 2009. Stakeholder Red Tape: Comparing Perceptions of Public Managers and Their Private Consultants. Public Administration Review 69(4): 710-26.

Feeney, Mary K., and Leisha DeHart-Davis. 2009. Bureaucracy and Public Employee Behavior: A Case of Local Government. Review of Public Personnel Administration 29(4): 311-26.

Frey, Bruno S. 1997. Not Just for the Money: An Economic Theory of Personal Motivation. Cheltenham: Edward Elgar.

Gagné, Marylene, and Edward L. Deci. 2005. Self-Determination Theory and Work Motivation. Journal of Organizational Behavior 26(4): 331-62.

Hattie, John. 2008. Visible Learning: A Synthesis of over 800 Meta-Analyses Relating to Achievement. London: Routledge.

Hjelmar, Ulf, Lene Holm Pedersen, and Mats J. Bordacconi. 2013. Det unødige bureaukrati: Sammenhangen med motivation, innovation og organisatoriske forhold. Copenhagen: Danish Institute for Local and Regional Government Research.

Jacobsen, Christian Bøtcher, Johan Hvitved, and Lotte Bøgh Andersen. 2014. Command and Motivation: How the Perception of External Interventions Relates to Intrinsic Motivation and Public Service Motivation. Public Administration 92(4): 790-806.

Jakobsen, Mads L., and Peter B. Mortensen. 2014. Det formelle fundament: Love, bekendtgørelser og unødigt bureaukrati. In Styring, ledelse og resultater på ungdomsuddannelserne, edited by Lotte Bøgh Andersen, Peter Bogetoft, Jørgen Grønnegaard Christensen, and Torben Tranæs, 33-51. Odense: University Press of Southern Denmark.

2016. Rules and the Doctrine of Performance Management. Public Administration Review 76(2): 302-12.

Jakobsen, Morten, and Rasmus Jensen. 2015. Common Method Bias in Public Management Studies. International Public Management Journal 18(1): 3-30.

Kaufman, Herbert. 1977. Red Tape: Its Origins, Uses and Abuses. Washington, DC: Brookings Institution.

Kaufmann, Wesley, and Mary K. Feeney. 2012. Objective Formalization, Perceived Formalization and Perceived Red Tape: Sorting Out Concepts. Public Management Review 14(8): 1195-1214.

Kaufmann, Wesley, and Arjen van Witteloostuijn. 2012. European and National Rules as Potential Red Tape Drivers: An Ecological Analysis of the Europeanization of Dutch Competition Law, 1962-2010. International Public Management Journal 15(3): 266-87.

Lan, Zhiyong, and Hal G. Rainey. 1992. Goals, Rules, and Effectiveness in Public, Private, and Hybrid Organizations: More Evidence on Frequent Assertions about Differences. Journal of Public Administration Research and Theory 2(1): 5-28.

Grand, Le, and Julian. 2010. Knights and Knaves Return: Public Service Motivation and the Delivery of Public Services. International Public Management Journal 13(1): 56-71.

Meier, Kenneth J., and Laurence J. O’Toole, Jr. 1999. Modeling the Impact of Public Management: Implications of Structural Context. Journal of Public Administration Research and Theory 9(4): 505-26.

Mikkelsen, Maria Falk, Christian Bøtcher Jacobsen, and Lotte Bøgh Andersen. 2017. Managing Employee Motivation: Exploring the Connections between Managers' Enforcement of Command Systems, Employee Perceptions, and Employee Intrinsic Motivation. International Public Management Journal 20(2): 183-205. 
Mintzberg, Henry. 1979. The Structuring of Organizations: A Synthesis of the Research. Englewood Cliffs, NJ: Prentice Hall.

1996. Managing Government, Governing Management. Harvard Business Review 74(3): 75-83.

Moynihan, Donald P., and Sanjay K. Pandey. 2007. The Role of Organizations in Fostering Public Service Motivation. Public Administration Review 67(1): 40-53.

Moynihan, Donald P., Sanjay K. Pandey, and Bradley E. Wright. 2012. Setting the Table: How Transformational Leadership Fosters Performance Information Use. Journal of Public Administration Research and Theory 22(1): 143-64.

Osborne, Stephen P. 2013. A Service Influenced Approach to Public Service Innovation? In Handbook of Innovation in Public Services, edited by Stephen P. Osbourne, and Louise Brown, 60-71. Northampton, MA: Edward Elgar.

O’Toole, Laurence J., Jr., and Kenneth J. Meier. 2011. Public Management: Organizations, Governance, and Performance. Cambridge: Cambridge University Press.

Ouchi, William G. 1980. Markets, Bureaucracies, and Clans. Administrative Science Quarterly 25(1): 129-41.

Pandey, Sanjay K., David H. Coursey, and Donald P. Moynihan. 2007. Organizational Effectiveness and Bureaucratic Red Tape: A Multimethod Study. Public Performance and Management Review 30(3): 398-425.

Pandey, Sanjay K., and Gorden A. Kingsley. 2000. Examining Red Tape in Public and Private Organizations: Alternative Explanations from a Social Psychological Model. Journal of Public Administration Research and Theory 10(4): 779-99.

Pandey, Sanjay K., and Donald P. Moynihan. 2006. Bureaucratic Red Tape and Organizational Performance: Testing the Moderating Role of Culture and Political Support. In Public Services Performance: Perspectives on Measurement and Management, edited by George A. Boyne, Kenneth J. Meier, Laurence J. O’Toole, Jr., and Richard M. Walker, 130-51. New York: Cambridge University Press.

Pandey, Sanjay K., and Patrick G. Scott. 2002. Red Tape: A Review and Assessment of Concepts and Measures. Journal of Public Administration Research and Theory 12(4): 553-80.

Perry, James L., Annie Hondeghem, and Lois Recascino Wise. 2010. Revisiting the Motivational Bases of Public Service: Twenty Years of Research and an Agenda for the Future. Public Administration Review 70(5): 681-90.
Podsakoff, Philip M., and Dennis W. Organ. 1986. Self-Reports in Organizational Research: Problems and Prospects. Journal of Management 12(4): 531-44.

Ritz, Adrian. 2009. Public Service Motivation and Organizational Performance in Swiss Federal Government. International Review of Administrative Sciences 75(1): 53-78.

Ryan, Richard M., and Edward L. Deci. 2000. Intrinsic and Extrinsic Motivations: Classic Definitions and New Directions. Contemporary Educational Psychology 25(1): 54-67.

Vandenabeele, Wouter. 2007. Toward a Public Administration Theory of Public Service Motivation. Public Management Review 9(4): 545-56.

Van Loon, Nina, Peter M. Leisink, Eva Knies, and Gene A. Brewer. 2016. Red Tape: Developing and Validating a New Job-Centered Measure. Public Administration Review 76(4): 662-73.

Van Witteloostuijn, Arjen, and Gjalt de Jong. 2010. Ecology of National Rule Birth: A Longitudinal Study of Dutch Higher Education Law, 1960-2004. Journal of Public Administration Research and Theory 20(1): 187-213.

Walker, Richard M., George A. Boyne, and Gene A. Brewer. 2012. Public Management and Performance: Research Directions. Cambridge: Cambridge University Press.

Walker, Richard M., and Gene A. Brewer. 2008. An Organizational Echelon Analysis of the Determinants of Red Tape in Public Organizations. Journal of Public Administration Research and Theory 68(6): 1112-27.

2009. Can Management Strategy Minimize the Impact of Red Tape on Organizational Performance? Administration \& Society 41(4): 423-48.

Wilson, James Q. 2000. Bureaucracy: What Government Agencies Do and Why They Do It, New ed. New York: Basic Books.

Wittrup, J. 2015. Calculation of Lifting Capacity in Upper Secondary Education. http://ps.au.dk/forskning/forskningsprojekter/leapledelsesadfaerd-og-performance/publikationer-og-papers/ [accessed September 14, 2017].

Wright, Bradley E., Donald P. Moynihan, and Sanjay K. Pandey. 2012. Pulling the Levers: Transformational Leadership, Public Service Motivation, and Mission Valence. Public Administration Review 72(2): 206-15. 


\section{Appendix}

Table A1 Exploratory Factor Analyses of Perceived Red Tape Measure (96 principals, 2,890 teachers)

\begin{tabular}{|c|c|c|c|c|c|c|}
\hline & \multicolumn{3}{|c|}{ Principals } & \multicolumn{3}{|c|}{ Teachers } \\
\hline & $\begin{array}{c}\text { Mean } \\
(S D)\end{array}$ & $\begin{array}{c}\text { Factor } \\
\text { Loading }\end{array}$ & $\begin{array}{l}\text { Cronbach's } \\
\text { Alpha }\end{array}$ & $\begin{array}{c}\text { Mean } \\
(S D)\end{array}$ & $\begin{array}{l}\text { Factor } \\
\text { Loading }\end{array}$ & $\begin{array}{l}\text { Cronbach's } \\
\text { Alpha }\end{array}$ \\
\hline $\begin{array}{l}\text { Rules and procedures make work processes in the organization more } \\
\text { troublesome than they need to be. }\end{array}$ & $\begin{array}{c}3.15 \\
(1.04)\end{array}$ & 0.70 & & $\begin{array}{c}3.23 \\
(1.09)\end{array}$ & 0.75 & \\
\hline $\begin{array}{l}\text { The rules and procedures I must follow in carrying out my primary work tasks } \\
\text { are very time consuming. }\end{array}$ & $\begin{array}{c}2.90 \\
(1.01)\end{array}$ & 0.83 & & $\begin{array}{c}3.12 \\
(1.08)\end{array}$ & 0.85 & \\
\hline Existing rules make it difficult to fulfill the actual purpose of my work. & $\begin{array}{c}2.71 \\
(1.05)\end{array}$ & 0.80 & & $\begin{array}{c}2.78 \\
(1.05)\end{array}$ & 0.82 & \\
\hline & & & 0.84 & & & 0.87 \\
\hline
\end{tabular}

Table A2 Descriptive Statistics

\begin{tabular}{|c|c|c|c|c|c|}
\hline & Variable & Mean & SD & Min. & Max. \\
\hline (1) & School performance & 0.00 & 0.07 & -0.16 & 0.19 \\
\hline (2) & Lagged school performance & 0.00 & 0.08 & -0.19 & 0.23 \\
\hline (3) & Perceived red tape, teachers (3-15) & 8.90 & 0.99 & 5.86 & 11.3 \\
\hline (4) & Perceived red tape, principal (3-15) & 8.45 & 2.55 & 4 & 15.0 \\
\hline (5) & Teachers' mean age (years) & 46.51 & 3.24 & 39.73 & 55.75 \\
\hline (6) & Teachers' mean tenure (years) & 12.19 & 3.94 & 0.00 & 22.00 \\
\hline (7) & $\%$ male teachers & 0.53 & 0.15 & 0.00 & 1.00 \\
\hline (8) & $\%$ part-time employed & 0.18 & 0.11 & 0.00 & 0.67 \\
\hline (9) & $\%$ science teachers & 0.22 & 0.14 & 0.00 & 0.64 \\
\hline (10) & Teachers' mean number of subjects & 2.15 & 0.29 & 1.50 & 3.33 \\
\hline (11) & $\%$ unionized teachers & 0.94 & 0.07 & 0.67 & 1.00 \\
\hline (12) & Principal tenure & 11.36 & 7.76 & 0.00 & 33.00 \\
\hline (13) & Principal gender $($ male $=1)$ & 0.80 & 0.40 & 0.00 & 1.00 \\
\hline (14) & School size (no. of teachers) & 70.35 & 31.73 & 7.00 & 164.00 \\
\hline \multicolumn{6}{|c|}{ Degree type } \\
\hline (15) & General upper secondary school & 0.72 & 0.45 & 0.00 & 1.00 \\
\hline (16) & Technical upper secondary school & 0.09 & 0.28 & 0.00 & 1.00 \\
\hline (17) & Business upper secondary school & 0.20 & 0.40 & 0.00 & 1.00 \\
\hline
\end{tabular}




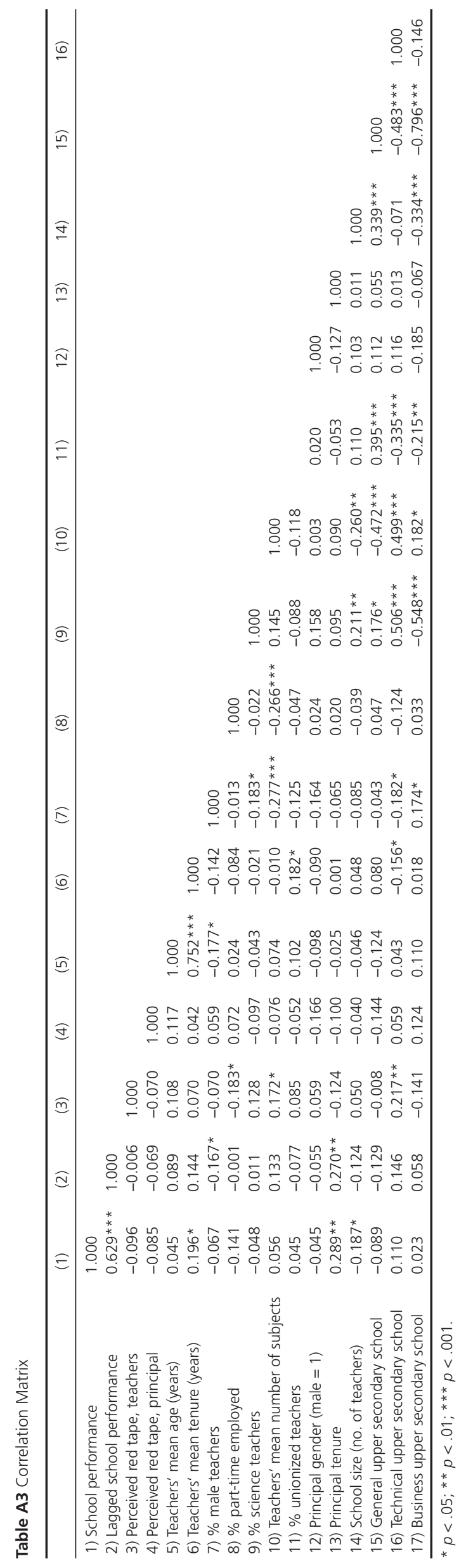

36 Public Administration Review • January|February 2018 